\title{
SITES DAS SECRETARIAS DE TURISMO DA REGIÃO NORDESTE DO BRASIL: DIALOGISMO, IMAGENS EM DISCURSO(S) E CONFIABILIDADE
}

\author{
TOURISM SECRETARY SITES FROM BRAZIL'S NORTHEAST REGION: \\ DIALOGISM, IMAGES IN DISCOURSE(S) AND CONFIABILITY
}

\author{
Rodrigo Acosta Pereira \\ Professor de Linguística da UFRN \\ Gianka Salustiano Bezerril \\ Professora de Linguística da UFRN \\ José Agostinho Barbosa de Souza \\ Acadêmico do Mestrado em Turismo na UFRN
}

\section{Resumo}

Frente às diversas perspectivas de estudos em Linguística Aplicada (LA) na contemporaneidade, objetivamos apresentar resultados parciais do estudo acerca dos sistemas de intermediação turística na região nordeste do Brasil. Para tanto, no presente estudo, investigamos como se constroem discursivamente os sites das secretarias de turismo (SETUR) dessa região, procurando compreender não apenas as imagens em discurso que se engendram no enunciado desses sites, como também as relações dialógicas que se constituem em conjunto. Metodologicamente, utilizamos as proposições dos escritos do Círculo de Bakhtin, para o estudo sociológico da linguagem, assim como alguns resultados de pesquisas atuais de seus interlocutores no campo da Análise Dialógica de Discurso. A pesquisa apresenta-se relevante, à medida que não apenas contribui para a consolidação de caminhos transdisciplinares em LA, como colabora para ratificação de estudos dialógicos do discurso nesse campo da ciência.

Palavras-chave: sites das SETURs; dialogismo; imagens em discurso; confiabilidade

\begin{abstract}
We aim at presenting partial results about the tourism media mediation in the Brazilian northwest region. To do so, in this study, the first part of a major project, we investigate how the discourse images and the dialogical relationships are constructed in the tourism secretaries sites from Brazilian northwest region. Methodologically, we review not only Circle's Bakhtin works, but also his contemporary interlocutors in the Dialogical Discourse Analysis area.
\end{abstract}

Keywords: SETURs sites; dialogism; images in discourse; confiability

\section{INTRODUÇÃO}

Diferentes pesquisas nos campos da Linguística Aplicada, Linguística, Antropologia, Psicologia, dentre outras áreas das Ciências Sociais e Humanas têm buscado compreender como nossas práticas de interação são consubstanciadas e perpassadas por valores sociais, históricos e ideológicos materializados textualmente por meio de discurso(s). Essas pesquisas ora situam-se em campos da análise de discurso de tradição 
francesa, ou de tradição anglosaxã, ora sob a ordem dos escritos do Círculo de Bakhtin, por exemplo. Nosso estudo situa-se no campo dos estudos bakhtinianos de discurso a partir dos escritos de Mikhail Bakhtin e o Círculo de intelectuais que, com ele, desenvolveram uma série de investigações sobre a linguagem, a ética, a estética e a cognição durante o período de 1919 a 1974 na Rússia. Em adição, retomamos as pesquisas dos interlocutores atuais do Círculo no campo da Análise Dialógica de Discurso, área em consolidação no campo da Linguística Aplicada. A fim de um percurso transdisciplinar de investigação do discurso, em adição, reenunciamos as pesquisas sociológicas de Giddens (1991; 1997) objetivando entender como se constroem, nos sites, efeitos de confiabilidade, à luz das discussões atuais do autor sobre a confiança em sistemas abstratos e peritos.

Objetivamos em nossa pesquisa investigar a construção dialógica do(s) discurso(s) que se confrontam na arquitetônica enunciativa de páginas eletrônicas de secretarias de turismo (SETURs) da região nordeste do Brasil. Para tanto, buscamos o acesso aos sites governamentais das secretarias de turismo dos estados da Bahia (BA), Sergipe (SE), Alagoas (AL), Pernambuco (PE), Paraíba (PB), Rio Grande do Norte (RN), Ceará (CE), Maranhão (MA) e Piauí (PI), procurando compreender quais as imagens em discurso que dialogicamente se confrontam na dimensão verbo-visual enunciativa desses sites. Entendemos que a presente investigação torna-se relevante, à medida que não apenas contribui para as pesquisas em Linguística Aplicada à luz dos escritos do Círculo de Bakhtin, como, em adição, colabora para o advento teórico-metodológico da análise dialógica de discurso em outras áreas das Ciências Sociais e Humanas, como o Turismo, por exemplo.

Nosso estudo assim está organizado: na primeira seção está situada nossa introdução; na segunda seção, apresentamos a revisão teórica sobre o conceito de discurso do Círculo; em nossa terceira seção, por sua vez, apresentamos algumas das discussões atuais de Giddens sobre a modernidade reflexiva e confiança em sistemas abstratos; na quarta seção, delineamos nossos pressupostos metodológicos de coleta e análise do corpus, isto é, nossa postura dialógica frente aos nossos dados, por excelência, dialógicos. Em nossa quinta seção, introduzimos nossa análise do(s) discurso(s) que entram em relações dialógicas de confronto nas páginas eletrônicas selecionadas e, por fim, em nossas considerações finais, direcionamos o leitor às avaliações gerais sobre os resultados e às propostas de (possíveis) futuras pesquisas na área.

\section{O DISCURSO NOS ESCRITOS DO CÍRCULO DE BAKHTIN: OS ENUNCIADOS E AS RELAÇÕES DIALÓGICAS}

Bakhtin (2008[1929] $]^{1}$ ) inicia o capítulo “O discurso em Dostoiévski”, em Problemas da Poética de Dostoiévski, afirmando que, por discurso, podemos entender a língua em sua concretude, em sua dinâmica social. A língua enquanto prática viva, interativa. $\mathrm{O}$ autor assim explica:

\footnotetext{
${ }^{1}$ Em todas as obras de Bakhtin, apresentamos duas datas, a da edição consultada e, entre colchetes, da (provável) escritura ou primeira publicação do texto, conforme cronologia indicada por Brait (2009, p. 9-10).
} 
[...] temos em vista o discurso, ou seja, a língua em sua integridade concreta e viva e não a língua como objeto específico da linguística ${ }^{2}$, obtido por meio de uma abstração absolutamente legítima e necessária de alguns aspectos da vida concreta do discurso. (BAKHTIN, 2008[1929], p. 207, grifos do autor).

Bakhtin (2008[1929]) está, a partir dessa explicação, procurando esclarecer que estudar o discurso pressupõe uma nova postura epistemológica frente aos postulados da linguística objetiva, imanente e sistêmica. Para o autor, esse percurso de análise da língua em sua concretude viva e dialógica estaria situado num campo outro de estudos da linguagem, o que Bakhtin (2008[1929], p. 207) denominaria de metalingüística ${ }^{3}$. Em termos bakhtinianos, a metalingüística estaria preocupada com as questões acerca dos diversos aspectos multifacéticos da vida concreta do discurso. Contudo, ressalta que, mesmo situando em um campo outro de estudos linguísticos, a metalingüística não ignora a linguística e pode/deve ainda se ocupar de seus resultados. Reenunciamos o autor: "A linguística e a metalingüística estudam um mesmo fenômeno concreto [...] - o discurso, mas estudam sob diferentes aspectos [...] (BAKHTIN, 2008[1929], p. 207), e ainda Bakhtin reitera, “devem completar-se mutuamente e não fundir-se.” (p. 207).

Bakhtin (2008[1929]) entende que o estudo do discurso deve estar sob a ordem do ângulo dialógico de onde os discursos ascendem e, por conseguinte, se confrontam, isto é, entram em relações semântico-valorativas. De acordo com o autor, o ângulo dialógico dos discursos não pode ser estabelecido via ordem metodológica restritamente linguístico-objetiva, por critérios essencialmente linguísticos, mas sob a ordem dos estudos das relações dialógicas. Por relações dialógicas, o autor compreende as diferentes relações semânticas e valorativas que engendram e se engendram no discurso. São relações que, como bem situa o autor, pertencem ao campo da metalinguística.

Na linguagem, enquanto objeto da linguística, não há e nem pode haver quaisquer relações dialógicas: estas são impossíveis entre os elementos no sistema da língua (por exemplo, entre as palavras no dicionário, entre os morfemas, etc.) ou entre elementos do "texto" num enfoque rigorosamente linguístico deste. Elas tão pouco podem existir entre as unidades de um nível nem entre as unidades de diversos níveis.

Não podem existir, evidentemente, entre as unidades sintáticas, por exemplo, entre as orações vistas de uma perspectiva rigorosamente linguística. Não pode haver relações dialógicas tampouco entre textos, vistos também sob a perspectiva rigorosamente linguística. Qualquer confronto puramente linguístico ou agrupamento de quaisquer textos abstrai forçosamente todas as relações dialógicas entre eles enquanto enunciados integrais. (BAKHTIN, 2008[1929], p. 208-209, grifos do autor).

2 Bakhtin, nesse trecho, faz referência à linguística de sua época, especificamente ao que o autor denomina de uma visão objetivista abstrata de língua (BAKHTIN [VOLOSHINOV, 2006[1929]).

3 "Para muitos pesquisadores, pela significação dominante que a palavra metalinguística possui no ocidente, o termo mais adequado seria translinguística. Nesse grupo de disciplinas, poderíamos hoje incluir as diferentes vertentes da análise de discurso, teorias da enunciação, semântica de vezo discursivo e a linguística aplicada, por exemplo.” (RODRIGUES, 2005, p. 156, grifos da autora). 
Sob a ótica bakhtiniana, o estudo do discurso implica, de forma natural e não categórica, o estudo das relações dialógicas. Estas, por sua vez, não podem ser investigadas pelo escopo linguístico strictu sensu, mas podem se ocupar de seus resultados, de maneira complementar com a visão teórico-metodológica da metalinguística. Bakhtin (2008[1929]) ainda afirma que as relações dialógicas são, de fato, não linguísticoobjetivas, mas extralinguísticas, isto é, são, por natureza, discursivas. Como para o autor discurso pressupõe a língua enquanto fenômeno integral concreto; a língua só se estabelece concretamente na comunicação dialógica, seu verdadeiro campo vivo de atuação. "Toda a vida da linguagem, seja qual for seu campo de emprego [...] está impregnada de relações dialógicas [...]. Estas relações situam-se no campo do discurso, pois este é, por natureza, dialógico [...].” (BAKHTIN, 2008[1929], p. 209).

Em adição a situar o estudo das relações dialógico-discursivas no campo da metalinguística, Bakhtin (2008[1929]) procura explicar os aspectos diferenciais entre as relações lógicas e as dialógicas no estudo da língua. Para o autor, as relações lógicas da língua (por exemplo, as relações morfossintáticas ou sintático-semânticas) carecem de ângulo dialógico e, portanto, não podem ser estudados sob a ordem discursiva. As relações lógicas, para serem estudadas dialogicamente, devem personificar-se na linguagem, devem tornar-se enunciados, convertidos em posições de diferentes sujeito expressos valorativamente na língua.

Diferentemente das teorias de Benveniste e de Ducrot ou ainda as discussões no campo da Linguística Textual, para Bakhtin (2003[1979]), os enunciados não se resumem a sentenças enunciadas, produtos da enunciação, mas são unidades de comunicação discursiva que se fundem, se integram na enunciação. $O$ discurso materializa-se na forma de enunciados que, em termos bakhtinianos, se caracterizam por três peculiaridades: a alternância de sujeitos discursivos, a expressividade axiológica e o dixi conclusivo.

Em relação à alternância dos sujeitos discursivos, Bakhtin (2003[1979], p. 275-278) explica que corresponde à alternância de falantes, estejam estes de forma concreta face a face com o interlocutor (por exemplo, em uma conversa entre amigos no intervalo de aula), estejam discursivamente potencializados (por exemplo, na leitura de um texto). A alternância de interlocutores, dessa forma, pode acarretar uma atitude responsiva imediata (como na conversa com o colega), como uma atitude retardada, a posteriori, (como a compreensão do leitor frente aos diversos textos que lê ou escuta). O autor ainda explica que, "todo enunciado - da réplica sucinta (monovocal) do diálogo cotidiano ao grande romance ou tratado científico - tem, por assim dizer, um princípio absoluto e um fim absoluto [...].” (BAKHTIN, 2003[1979], p. 275). Em outras palavras, "antes do seu início, os enunciados de outros; depois do seu término, os enunciados responsivos de outros [...]. O falante termina o seu enunciado para passar a palavra ao outro ou dar lugar à sua compreensão ativamente responsiva.” (BAKHTIN, 2003[1979], p. 275).

Quanto à expressividade, Bakhtin (2003[1979]) nos esclarece que todo enunciado se manifesta sob a ordem de uma determinada entonação expressiva. Para o autor, o discurso, materializado na forma de enunciados orais, escritos ou de outra manifestação semiótica, sempre incluem em sua estrutura uma entonação expressiva, isto é, requerem 
um tom. Essa expressividade valorativa que consubstancia o enunciado pode assumir, por exemplo, tons secos, tons de coação ou ainda tons mais calorosos, íntimos, a depender da situação de enunciação. Segundo Bakhtin (2003[1979], p. 284), é possível ainda uma reacentuação do discurso, à medida que podemos transferir um enunciado de uma esfera discursiva para outra com determinadas intenções (por exemplo, um enunciado da esfera oficial para a esfera familiar com uma reacentuação irônicoparódica, como explica o autor).

A conclusibilidade, por sua vez, diz respeito ao dixi conclusivo de todo e qualquer enunciado. Para o autor, o dixi compreende uma espécie de aspecto interno da alternância de sujeitos discursivos. "Essa alternância pode ocorrer precisamente porque o falante disse (ou escreve) tudo o que quis dizer em dado momento ou sob dadas condições.” (BAKHTIN, 2003[1979], p. 280, grifos do autor). O autor ainda explica que a conclusibilidade é determinada por elementos específicos, são eles: (i) a exauribilidade semântico-objetal do tema do enunciado; (ii) a intenção discursiva de discurso e (iii) formas estáveis de gêneros de enunciado.

O primeiro critério corresponde ao tema que cada enunciado se constrói. Pode ser quase extremamente pleno em esferas de natureza factual/institucionalizada (como, por exemplo, ordens legais, cartas comerciais, etc.), onde são esferas que tipificam situações de interação de natureza mais relativamente padronizada e onde o elemento criativo é quase inexistente. Ainda podem abarcar certa criatividade, em esferas onde é "possível uma única exauribilidade semântico-objetal relativa [...].” (BAKHTIN, 2003[1979], p. 281). O segundo critério diz respeito à vontade discursiva do falante, que, para o autor, determina todos os limites e fronteiras do enunciado. "Imaginamos o que o falante quer dizer, e com essa ideia verbalizada, essa vontade verbalizada (como a entendemos) é que medimos a conclusibilidade do enunciado.” (BAKHTIN, 2003[1979], p. 281, grifos do autor). O terceiro critério, por sua vez, corresponde às formas típicas de gêneros do discurso. Para Bakhtin (2003[1979], p. 282, grifos do autor), "falamos apenas através de determinados gêneros do discurso, isto é, todos os nossos enunciados possuem formas relativamente estáveis e típicas de construção do todo." A intenção discursiva de discurso se realiza na escolha de um gênero ${ }^{4}$ específico que, por sua vez, é determinado pela especificidade de uma esfera da comunicação discursiva, “por considerações semântico-objetais (temáticas), pela situação concreta da comunicação discursiva, pela composição pessoal dos seus participantes.” (BAKHTIN, 2003[1979], p. 282.).

Com base nesses pressupostos teóricos e metodológicos, reiteramos que, nesse estudo, objetivamos apresentar uma análise dos discursos que se relacionam dialogicamente nos enunciados materializados nos sites das SETURs da região nordeste do Brasil. Para tanto, recuperamos os conceitos de discurso, de relações dialógicas e de enunciados do Círculo de Bakhtin, pois entendemos que o discurso dos sites se materializa na forma de enunciados concretos que se relacionam dialogicamente construindo determinados

\footnotetext{
${ }^{4}$ Não objetivamos no presente estudo introduzir explicações extensivas sobre o conceito de gêneros do discurso à luz dos escritos de Bakhtin. Direcionamos o leitor para a leitura de trabalhos como de Acosta-Pereira (2008; 2010; 2011a; 2011b); Rodrigues (2001; 2005), Rohling da Silva (2008); Machado (2007), dentre outros.
} 
efeitos de sentidos, levando o leitor a determinadas atitudes responsivas especificamente valoradas e delineadas pela vontade discursiva do sujeito da linguagem.

\title{
3 CONFIANÇA EM SISTEMAS PERITOS: A DISPOSIÇÃO E A BUSCA DE INFORMAÇÕES TURÍSTICAS EM SITES INSTITUCIONAIS DO GOVERNO
}

Haja vista nosso objetivo geral de entender como os sites das SETURs dos estados da região nordeste do país apresentam suas informações para o público, procuramos dialogar, em adição aos escritos bakhtinianos, com as postulações atuais de Giddens (1991[1990]; 1997) sobre as transformações de confiança nas práticas que interagimos e nos discursos que, por sua vez, medeiam essas práticas. Como explica-nos o autor,

\begin{abstract}
Os modos de vida produzidos pela modernidade nos desvencilharam de todos os tipos tradicionais de ordem social, de uma maneira que não têm precedentes. Tanto em sua extensionalidade quanto em sua intensionalidade, as transformações envolvidas na modernidade são mais profundas que a maioria dos tipos de mudança característicos dos períodos precedentes. Sobre o plano extensional, elas serviram para estabelecer formas de interconexão social que cobrem o globo; em termos intensionais, elas vieram a alterar algumas das mais íntimas e pessoais características de nossa existência cotidiana. Existem, obviamente, continuidades entre o tradicional e o moderno, e nem um nem o outro formam um todo à parte; é bem sabido o quão equívoco pode ser contrastar a ambos de maneira grosseira. (GIDDENS, 1991[1990], p. 14, grifos do autor).
\end{abstract}

Podemos perceber como as instituições sociais modernas têm alcançados diferentes transformações, seja de âmbito extensional, seja intensional. Essas transformações têm sido significadas por um universo de eventos que, para muitos, parecem estar fora de controle. Parece haver certos deslocamentos.

Para Giddens (1991[1990]; 1997), esses deslocamentos sugerem que as transformações institucionais estão se movimentando de um eixo baseado na manufatura de bens materiais para um eixo centrado no sistema de informações. Isso se comprova, segundo o autor, a partir de três características centrais: (i) o ritmo de mudança; (ii) o escopo de mudança e (iii) a natureza intrínseca das instituições modernas.

O ritmo de mudança diz respeito à extrema rapidez de transformações das civilizações tradicionais para as condições de modernidade, pois "as civilizações tradicionais podem ter sido consideravelmente mais dinâmicas que outros sistemas pré-modernos, mas a rapidez da mudança em condições de modernidade é extrema.” (GIDDENS, 1991[1990], p. 15). Em relação ao escopo de mudança, para o autor, "conforme diferentes áreas do globo são postas em interconexão, ondas de transformação social penetram virtualmente toda a superfície da Terra.” (GIDDENS, 1991[1990], p. 16). A terceira característica, por sua vez, diz respeito a como "algumas formas sociais modernas simplesmente não se encontram em períodos históricos precedentes [...]. Outras têm apenas uma continuidade especiosa com ordens sociais pré-existentes.” (GIDDENS, 1991[1990], p. 16). 
Em relação aos sites institucionais das SETURs da região nordeste, entendemos que, ao disponibilizar informações, tais páginas estão, por assim dizer, possibilitando, sem dimensões de tempo e espaço definidas, o acesso a informações de maneira ilimitada, viabilizando relações entre o público e as informações institucionais de forma globalizante, construindo, de acordo com Giddens (1991[1990], p. 29) um "deslocamento das relações sociais de contextos locais de interação e sua reestruturação através de extensões indefinidas de tempo-espaço.” Essa relação, para o autor, constrói o que podemos chamar de confiança em sistemas peritos.

A confiança em sistemas peritos está baseada nas discussões de Giddens (1991[1990]; 1997) acerca da confiabilidade em sistemas ditos fidedignos, à medida que, "em condições de modernidade, uma quantidade cada vez maior de pessoas vive em circunstâncias nas quais instituições desencaixadas, ligando práticas locais a relações sociais globalizadas, organizam os aspectos principais da vida cotidiana.” (GIDDENS, 1991[1990], p. 83).

Para Giddens (1991[1990], p. 87), a confiabilidade pode ser explicada a partir de duas direções: a confianaça estabelecida entre pessoas, "indivíduos que se conhecem bem e que, baseados num relacionamento de longo prazo, substanciaram as credenciais que tornam cada um fidedigno aos olhos do outro.” A outra direção está na confiança relativa, a confiança em sistemas abstratos, que "não pressupõe encontro algum com os indivíduos ou grupos que são de alguma forma responsáveis por eles.” Para o autor,

[...] a natureza das instituições modernas está profundamente ligada ao mecanismo da confiança em sistemas abstratos, especialmente em sistemas peritos. Em condições de modernidade, o futuro está sempre aberto, não apenas em termos da contingência comum das coisas, mas em termos de reflexidade do conhecimento em relação ao qual as práticas sociais são organizadas. [...] A fidedignidade conferida pelos atores leigos aos sistemas peritos não é apenas uma questão [...] de gerar uma sensação de segurança a respeito de um universo de eventos independentemente dado. É uma questão de cálculo de vantagem e risco em circunstâncias onde o conhecimento perito simplesmente não proporciona esse cálculo, mas na verdade cria (ou reproduz) o universo de eventos, como resultado da contínua implementação reflexiva desse próprio conhecimento. (GIDDENS, 1991[1990], p. 8788 , grifos do autor).

Podemos entender que, o público, ao acessar os sites dos SETURs, pode estar procurando, de forma mais segura, sejam dados sobre os locais, sejam informações factuais sobre localidades a serem visitadas. Os sites, por serem institucionais, podem, por assim dizer, criar um espaço fidedigno de acesso aos dados "supostamente verdadeiros” sobre as cidades. Há uma construção de confiança entre o público e as informações apresentadas nesses sites institucionais do governo.

Essa construção de confiabilidade se dá entre o público e os sistemas abstratos, como nesse caso, entre o público e os sites institucionais das SETURs dos estados que compõem a região nordeste do Brasil. "O mundo em que vivemos hoje é um mundo carregado e perigoso” (GIDDENS, 1991[1990], p. 19); criar elos de confiabilidade entre sujeitos e sistemas abstratos parece ser o caminho de reencaixe do estilo e costumes da vida na sociedade dita moderna. 


\section{PRESSUPOSTOS METODOLÓGICOS}

Primeiramente, reenunciamos Sobral (2009, p. 68) que explica que,

[...] o Círculo defende justamente que se entenda o discurso a partir da realidade concreta e dos sujeitos concretos, também não se pode ver no discurso a representação objetiva dessa realidade concreta, e desses sujeitos concretos, mas sim a imagem em discurso dessa realidade e desses sujeitos. (SOBRAL, 2009, p. 68, grifos nossos).

Recuperamos a voz de Sobral (2009), interlocutor contemporâneo de Bakhtin e o Círculo, para retomarmos a ideia inicial desse estudo de entender o discurso das páginas eletrônicas das SETURs da região nordeste do Brasil. De fato, objetivamos entender quais as imagens em discurso que se materializam na forma de enunciados nessas páginas e como, essa imagem, se constrói via relações dialógicas. Além disso, trazemos a explicação de Bakhtin [Volochinov] (2006[1929]) $)^{5}$ acerca do estudo sociológico da linguagem e de sua mudança. Como explicam os autores, "a língua vive e evolui historicamente na comunicação verbal concreta, não no sistema linguístico abstrato das formas da língua nem no psiquismo individual dos falantes." (BAKHTIN [VOLOCHINOV], 2006[1929], p. 128-129, grifos dos autores).

Sob essa perspectiva, e tendo em vista a língua como discurso, os autores apresentam as seguintes diretrizes metodológicas para o estudo linguístico:

1. As formas e os tipos de interação verbal em ligação com as condições concretas em que se realiza;

2. As formas das distintas enunciações, dos atos de fala isolados, em ligação estreita com a interação de que constituem os elementos, isto é, as categorias de atos de fala na vida e na criação ideológica que se prestam a uma determinação pela interação verbal;

3. A partir daí, exame das formas da língua na sua interpretação linguística habitual. [...] Enquanto um todo, a enunciação só se realiza no curso da comunicação verbal, pois o todo é determinado pelos seus limites, que se configuram pelos pontos de contato de uma determinada enunciação com o meio extraverbal $e$ verbal (isto é, as outras enunciações). (BAKHTIN [VOLOCHINOV], 2006[1929], p. 128-129, grifos nossos).

Como base nessas diretrizes, objetivamos analisar nossos dados, considerando a língua como discurso e este materializado na forma de enunciados concretos em dada situação interlocutiva. Para tanto, selecionamos nosso corpus, os sites das SETURs de cada estado da região nordeste. O que evidenciamos primeiramente, na coleta de dados, foi que as páginas eletrônicas das secretarias de turismo dos estados do RN e do PI, como exposto na tabela abaixo, não foram encontradas A escolha da região nordeste, frente às demais regiões do país, se deu pelos índices de crescimento na procura de destinos

\footnotetext{
${ }^{5}$ Concordamos com Rodrigues (2005), “Na citação dos textos publicados por Volochinov e Medvedev, seguirei a opção feita pelo tradutor, mas com a indicação, entre colchetes, da dupla autoria quando for o caso.” (RODRIGUES, 2005, p. 152).
} 
turísticos para essa região ${ }^{6}$ e pela procura de entendimento de como, uma das regiões consideradas de menor Índice de Desenvolvimento Humano (IDH) ${ }^{7}$ do país, tem se apresentado para o campo turístico, atraindo milhares de visitantes a todo ano. O universo dos dados encontra-se sintetizado no quadro a seguir.

Outra questão foi a escolha de sites $^{8}$ para análise. Acreditamos que, no campo das Ciências Sociais e Humanas têm crescido o interesse pela pesquisa acerca das práticas sociais e discursivas de situações de interação online. Dessa forma, ao investigar os sites institucionais das SETURs do nordeste, visamos, integrado ao nosso objetivo geral, a entender a linguagem online que se torna mediadora das interlocuções e das trocas de informações entre o público (a procura de informações turísticas) e a instituição (as SETURs, na apresentação de informações).

\begin{tabular}{|c|c|c|c|}
\hline Estado & Site da secretaria de turismo & $\begin{array}{l}\text { Denominação da } \\
\text { Secretaria }\end{array}$ & Categorização \\
\hline BA & http://www.setur.ba.gov.br/ & $\overline{\text { SETUR }}$ & SETURBA \\
\hline SE & http://www.turismosergipe.net/ & $\begin{array}{l}\text { Secretaria de } \\
\text { Turismo }\end{array}$ & SETURSE \\
\hline $\mathrm{AL}$ & http://www.turismo.al.gov.br/ & SETUR & SETURAL \\
\hline $\mathrm{PE}$ & http://www2.setur.pe.gov.br/web/setur & SETUR & SETURPE \\
\hline PB & $\begin{array}{l}\text { http://www.paraiba.pb.gov.br/turismo- } \\
\text { e-do-desenvolvimento-economico }\end{array}$ & $\begin{array}{l}\text { Secretaria de } \\
\text { Turismo e } \\
\text { Desenvolvimento } \\
\text { Econômico }\end{array}$ & SETURPB \\
\hline RN & Não foi encontrado & $\begin{array}{ll}\text { Secretaria } & \text { de } \\
\text { Estado } & \text { do } \\
\text { Turismo } & \end{array}$ & \# \\
\hline CE & http://www.setur.ce.gov.br/ & SETUR & SETURCE \\
\hline MA & http://www.turismo.ma.gov.br/ & SETUR & SETURMA \\
\hline PI & Não foi encontrado & SETUR & \# \\
\hline
\end{tabular}

Tabela 1. Universo dos dados.

A partir disso, nosso percurso de análise segue as seguintes direções: (i) análise descritivo-interpretativista do(s) discurso(s) que se entrecruzam na materialidade enunciativa das páginas eletrônicas das SETURs da região nordeste; (ii) análise das relações dialógicas que engendram e se engendram nesse entrecruzamento discursivo e (iii) os sentidos que se instauram por meio dessas relações dialógicas. Para tanto,

\footnotetext{
${ }^{6}$ Segundo a pesquisa "Hábitos de Consumo do Turismo Brasileiro 2009", realizada pelo Vox Populi em novembro de 2009, a Bahia é o destino turístico preferido dos brasileiros, já que 21,4\% dos turistas optaram pelo estado. Pernambuco, com 11,9\%, e São Paulo, com 10,9\%, estão, respectivamente, em segundo e terceiro lugares nas categorias pesquisadas no Brasil. Fonte: http://www.portalbrasil.net/regiao_nordeste.htm

7 Segundo dados em http://www.aneel.gov.br/aplicacoes/atlas/pdf/11\%C2\%ADAspectos_Socioe.pdf

${ }^{8}$ A procura de compreensão de práticas interacionais online ascendeu a partir de um levantamento breve sobre estudos contemporâneos construídos à luz do advento das Tecnologias de Informação e Comunicação nos campos da Linguística e da Linguística Aplicada. Verificamos a existência de poucos trabalhos na área de análise de discurso institucionais. Os estudos centram-se, em demasia, acerca do uso das tecnologias para as práticas de ensino e aprendizagem de línguas ou elaboração de material didático digital.
} 
seguiremos os pressupostos epistemológicos já mencionados, procurando compreender como "qualquer enunciação, por mais significativa e completa que seja, constitui apenas uma fração de uma corrente de comunicação verbal ininterrupta.” (BAKHTIN [VOLOCHINOV], 2006[1929], p. 128, grifos dos autores).

\section{AS IMAGENS EM DISCURSO(S) NA MATERIALIDADE ENUNCIATIVA DOS SITES GOVERNAMENTAIS}

Ao investigarmos as imagens em discursos que se confrontam nos sites das SETURs, procuramos, de fato, entender como, discursos, materializados na forma de enunciados concretos, projetam valores e posições ideológicas distintas e determinadas pela situação de interação. Os sites são construídos à luz de diferentes imagens discursivas, são elas: discurso político; discurso econômico; discurso do entretenimento; discurso da sustentabilidade e da eco-responsabilidade e discurso de responsabilidade social.

(a) O discurso político: imagens discursivas presentes nos sites que visam a abrir espaços para a socialização das ações políticas públicas para o advento do turismo no estado. É comum em todos os sites das SETURs a ocorrência do enquadramento do discurso da esfera política como marcas de credibilidade ou de ênfase da participação governamental nas ações de gestão turística. É claro que todo enunciado se integra à sua situação de interação e aos valores e posições ideológicas que se perpassam nessas situações. Dessa forma, não seria diferente, a presença de imagens em discurso político nos sites das SETURs.

Como podemos observar nas páginas, a imagem em discurso político constrói-se à luz de diferentes sentidos: i) o sentido de autorização; ii) o sentido de legalização; iii) o sentido de avaliação e iv) o sentido de validação. O sentido de autorização é construído com o intuito de tornar "autorizável” as informações apresentadas nos sites das SETURs, isto é, a imagem em discurso político autoriza a veracidade das informações turísticas apresentadas. Quanto ao sentido de legalização, as imagens em discurso político apresentam-se como "legalizadores" das informações, procurando construir um "diálogo legal” com o leitor. Em outras palavras, o sentido de legalização objetiva definir como "legais" as informações dadas. Vejamos a página abaixo da SETUR da Bahia, com vários hiperlinks que conduzem o leitor às informações políticas em relação ao turismo neste estado. 


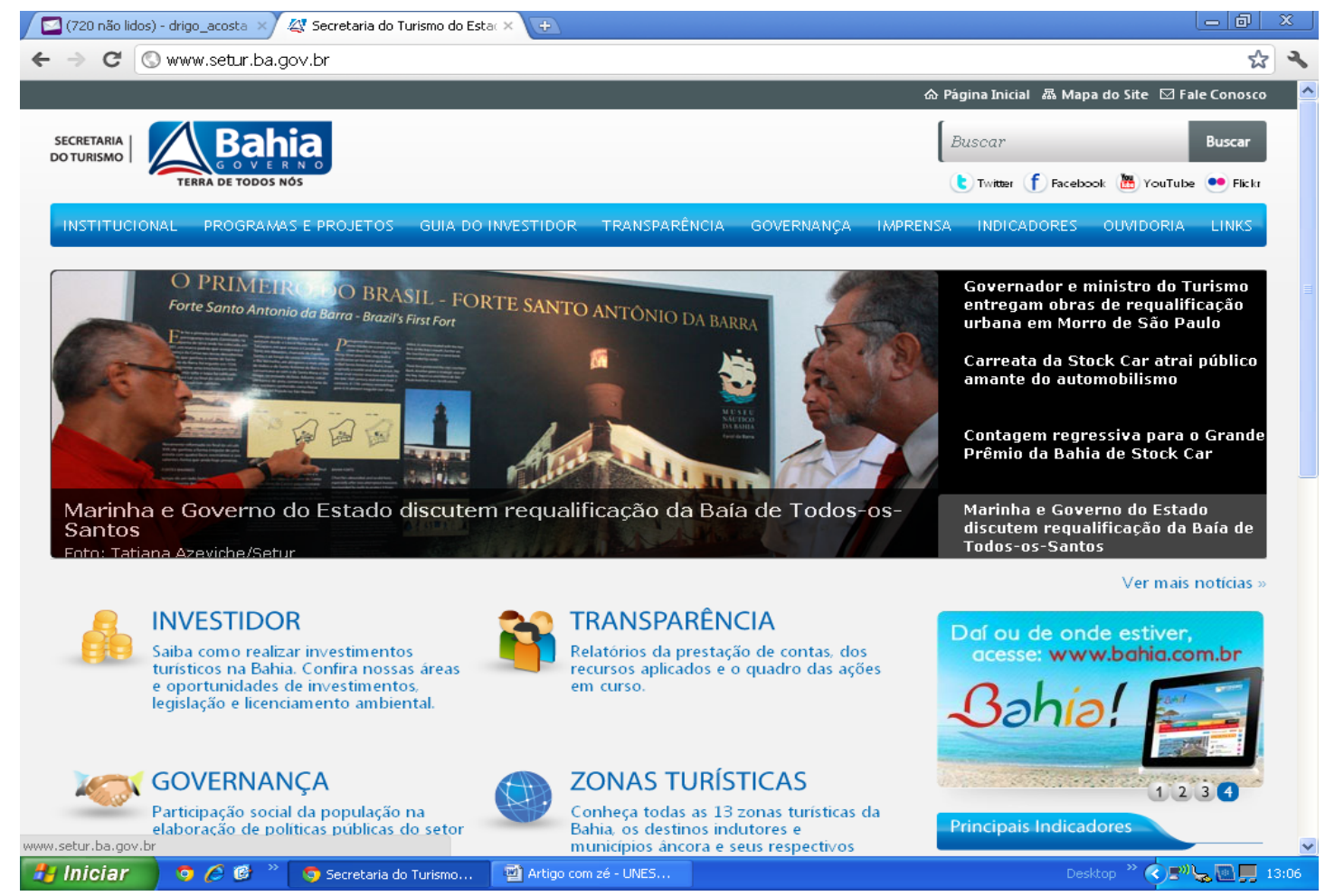

Imagem 1. Página virtual da SETURBA. http://www.setur.ba.gov.br/

O sentido de avaliação pode ser entendido como as imagens em discurso cujo propósito é julgar positivamente as informações turísticas dos sites das SETURs do nordeste. Procura-se, de fato, apresentar ao leitor dados, estatísticas e informações sobre o turismo na região nordeste como “as melhores" do país. Ë evidente que não seria diferente, à medida que, um dos objetivos interacionais das páginas das SETURs é a procura de adesão do leitor e de convencimento deste quanto à escolha de seu destino turístico.

O sentido de validação coaduna-se ao sentido de autorização e legalização, posto procurar "validar" as informações do site a partir de diferentes recursos estilísticos: (a) o enquadramento de fotografias de reuniões políticas dos estados; (b) enquadramento de fotografias de inaugurações com a participação de políticos dos estados; (c) o enquadramento de discurso reportados de outrem acerca do turismo no estado específico e (d) enquadramento de gêneros do discurso outros, como notícias, reportagens e entrevistas cujo horizonte temático esteja vinculado às obras ou ações políticas no estado específico. Ratificamos que esses recursos estilísticos que se engendram nas imagens em discurso político na construção de sentidos de validação, definem-se, por excelência, como relações dialógicas (Cf. seção 6).

(b) O discurso econômico: imagens discursivas da economia e de conteúdo semântico-objetais relacionáveis estão, em adição, presentes nos sites das SETURs. Haja vista a relação íntima com o discurso político, observamos que nos sites é comum o discurso econômico estar presente junto às informações turísticas. Essa ocorrência nos leva à ideia de Acosta-Pereira (2008) acerca das ressonâncias temáticas que se engendram nos mais diversos gêneros do discurso. Para o autor, todo conteúdo semântico-objetal 
de um enunciado nunca é preso ou estanque, mas pode entrar em relações de diálogo constitutivo com outros conteúdos (objetos do discurso).

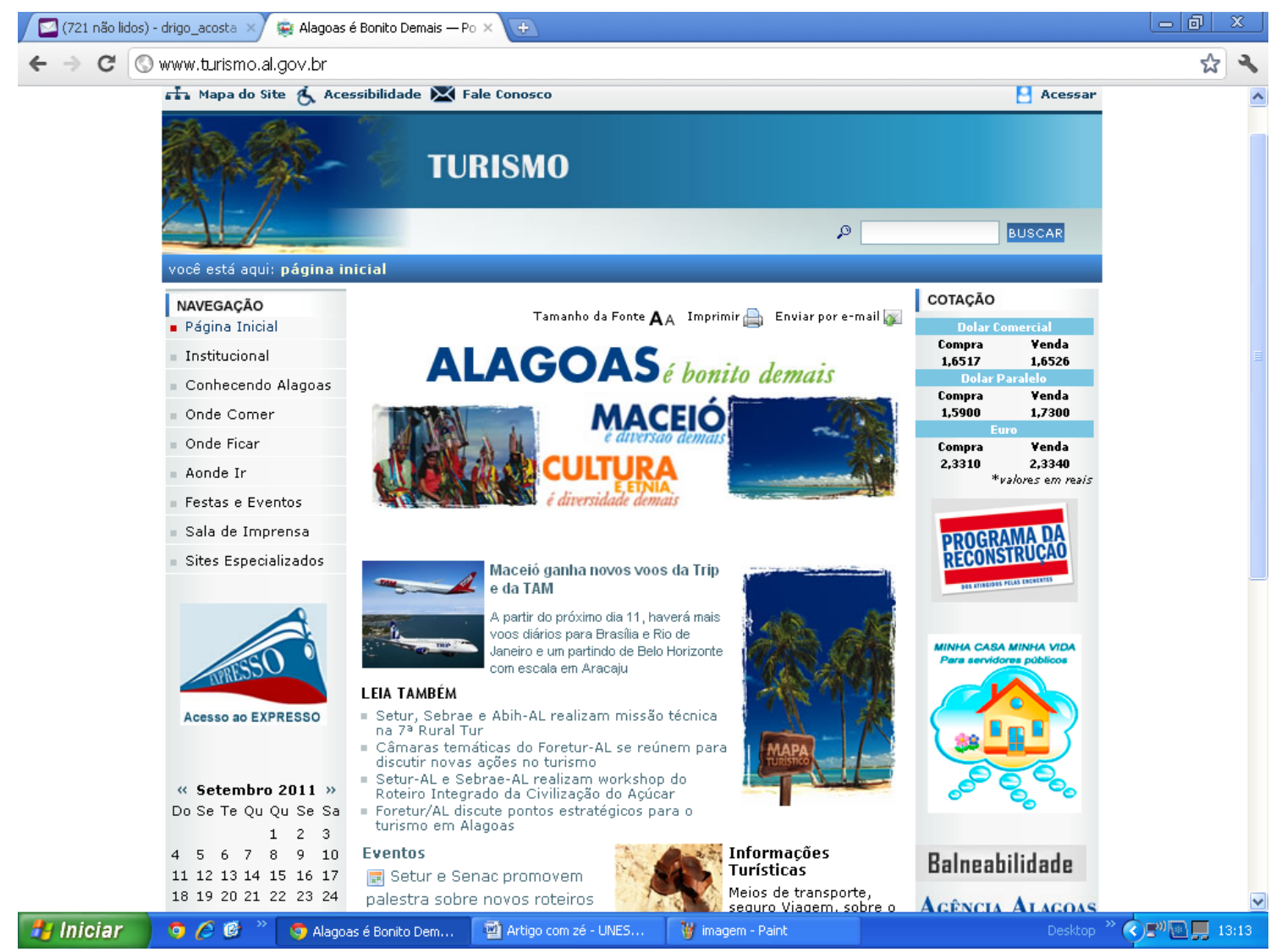

Imagem 2. Página virtual da SETURAL. http://www.turismo.al.gov.br/

As imagens de discurso econômico, por sua vez, se constroem nos sites por meios de diferentes efeitos de sentido: i) exaltação da economia do estado; ii) comparação de índices econômicos entre estados da mesma região; e iii) comparação de índices econômicos entre estados da região nordeste com estados de outras regiões do Brasil.

É perceptível nos sites das SETURs da região nordeste do país, a exaltação da economia de seus estados a partir da apresentação de gráficos com índices econômicos, tabelas comparativas e enquadramento de gêneros outros com o intuito de enaltecer a economia do nordeste e sua relação com o advento do turismo nessa região. Além disso, as páginas apresentam diversos hiperlinks que conduzem o leitor para quadros comparativos entre a região nordeste e seus estados, assim como entre os estados da região nordeste e outros estados do Brasil, sempre enaltecendo a região nordeste em relação às demais. Entendemos que nas páginas há sempre esse confronto de valores e de imagens em discurso (como por exemplo, entre imagens em discurso político e econômico), porque, como bem esclarece Sobral (2009),

[...] os enunciados /discursos são considerados um produto do processo de intercâmbio. Ao contrário de outros produtos, trata-se de um produto que só pode ser entendido se levarmos em conta o processo de sua produção, de sua circulação no mundo e de sua recepção por outros sujeitos, e só podemos considerar esse processo 
mediante o acesso ao seu produto. Assim, o produto “discurso" não é algo estabilizado, acabado, morto, independente da situação de sua produção; ele só passa a produzir sentido se entendido no âmbito desse processo e é nesse processo, portanto, que devemos procurar seu sentido. (SOBRAL, 2009, p. 90, grifos do autor).

Dessa forma, podemos entender que as imagens em discurso se constroem a partir dos sentidos pretendidos pelo sujeito autor e relativamente regularizados pela própria situação de interação, à medida que "[...] o modo de ser da linguagem envolve um processo de permanente negociação e regulação do sentido [...].” (SOBRAL, 2009, p. 90). Com isso, as imagens em discurso econômico, em confluência com as imagens de discurso político, trabalham em conjunto (assim como com as demais a seguir) para alcançar o objetivo específico dos sites das SETURs: alcançar a adesão do leitor e sua escolha pelo destino turístico na região nordeste do país.

(c) O discurso do entretenimento: imagens discursivas de entretenimento não poderiam estar ausente em sites de turismo, posto ser umas das metas dos mais diversos turistas à procura de informações. Mesmo sendo sites institucionais, o que nos levaria a crer que, em demasia, as informações se centrariam em imagens em discursos políticos, econômicos, por exemplo, todas as SETURs investigadas apresentam enunciativamente materializadas por imagens em discurso do entretenimento, o que se configura em outra relação dialógica entre conteúdos semântico-objetais.

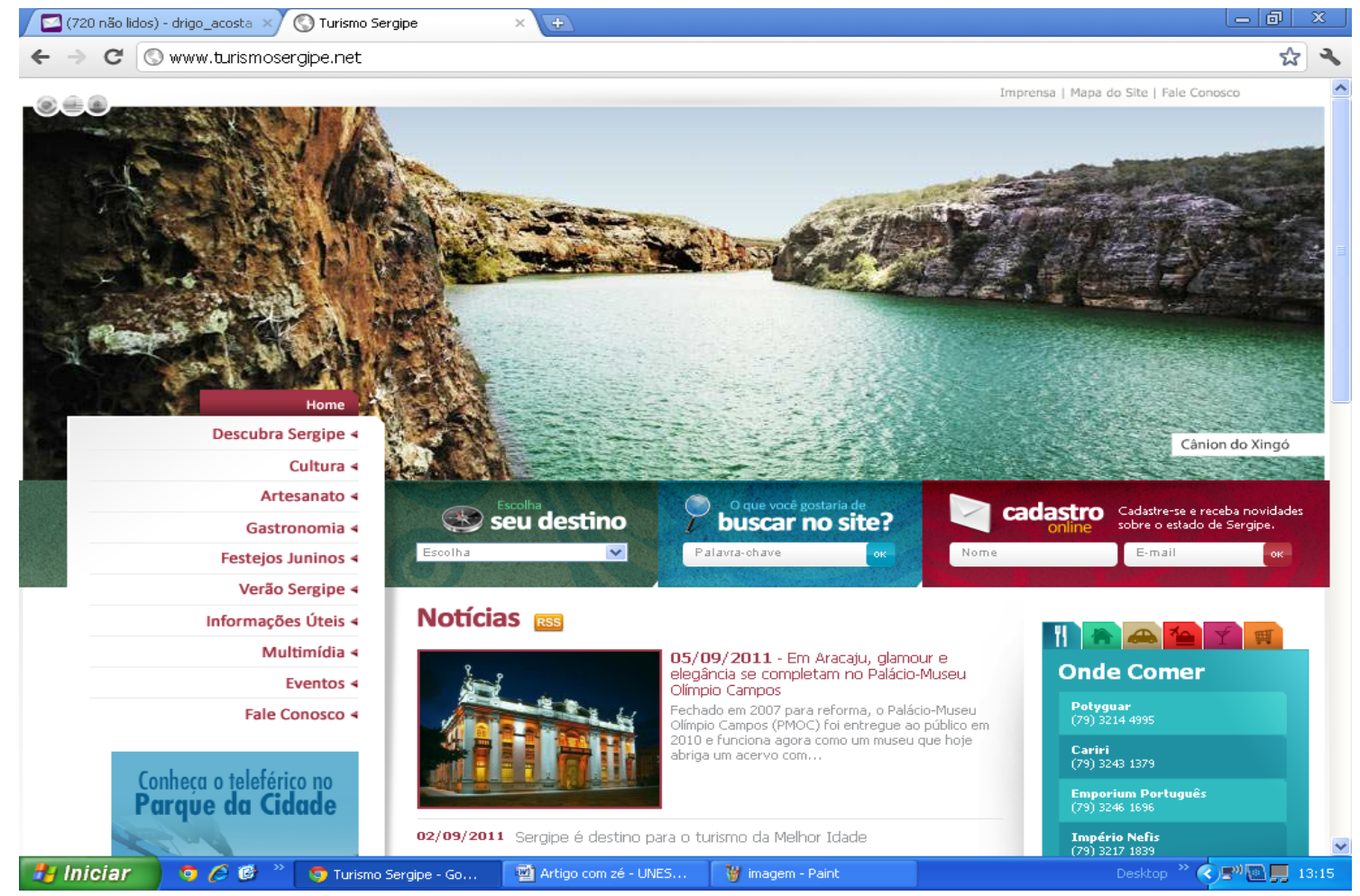

Imagem 3. A página virtual da SETURSE. http://www.turismosergipe.net/

(d) O discurso da sustentabilidade e da eco-responsabilidade: a preocupação em apresentar marcas discursivas de atenção à sustentabilidade e à 
responsabilidade ecológica são também imagens em discurso dos sites das SETURs. Todos os sites investigados apresentam imagens discursivas da sustentabilidade e da responsabilidade ecológica com seus estados. Como afirma Giddens (2010), uma das preocupações centrais das instituições modernas é com a consciência sustentável, as mudanças climáticas, os perigos atuais e as políticas de adaptação. Os sites das SETURs reiteram essa afirmação.

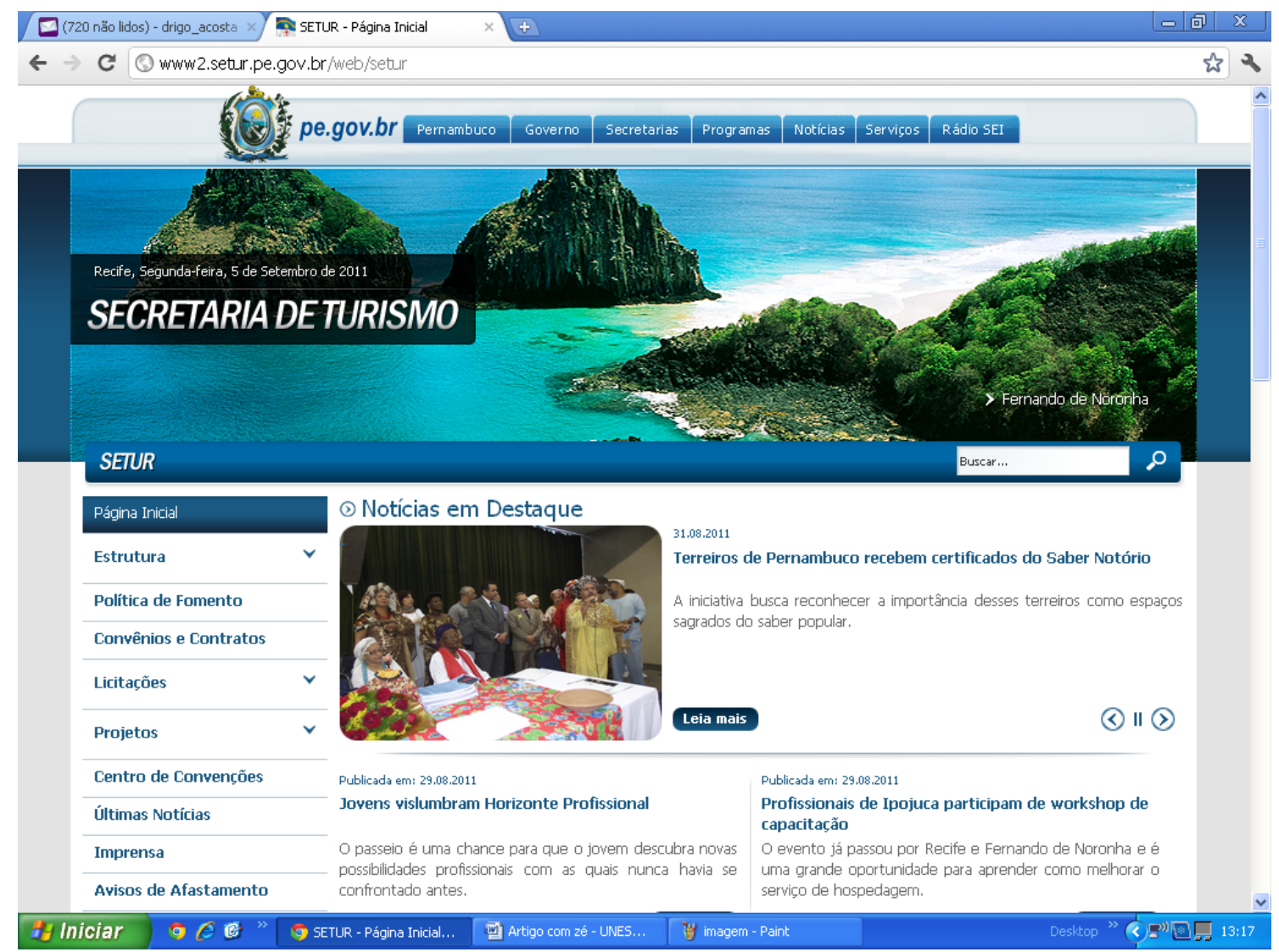

Imagem 4. Página virtual da SETURPE. http://www2.setur.pe.gov.br/web/setur

(e) O discurso da responsabilidade social: por discurso de responsabilidade social, entendemos nessa investigação, a preocupação das SETURs em apresentar o turismo como um caminho de ascensão social das comunidades. Ligado às imagens de discurso da política e da economia, o discurso de responsabilidade social se conjuga às essas imagens construindo marcas de avaliação e validação das informações presentes: a participação do turismo como um dos propulsores do crescimento econômico dos estados. Acreditamos que, mais uma vez, as imagens em discurso se relacionam construindo dialogicamente sentidos valorados acerca do turismo na região nordeste: um discurso em que as políticas públicas estão a serviço do crescimento econômico e da responsabilidade sustentável do turismo nesses estados. 


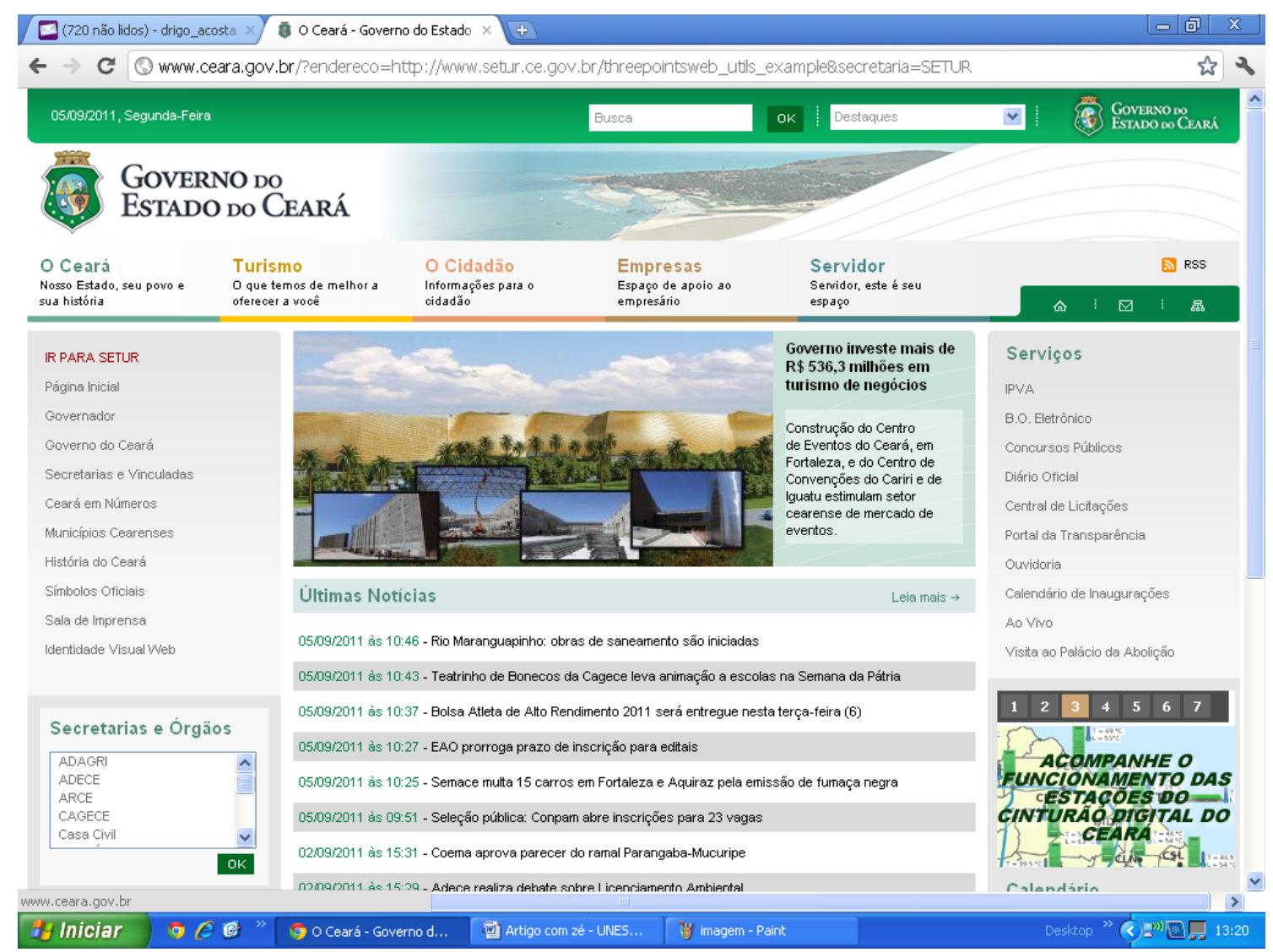

Imagem 5. A página virtual da SETURCE. http://www.ceara.gov.br/SETUR

Outra questão que a análise nos leva a compreender é que, as imagens em discurso que se materializam enunciativamente nesses sites são construídas por meio de diferentes relações semântico-valorativas, isto é, relações dialógicas que constituem o(s) discurso(s) dos sites das SETURs. Entendemos que essas relações se consubstanciam por meio: (i) da reenunciação do discurso de outrem; (ii) das ressonâncias entre esferas discursivas; (iii) do enquadramento de gêneros intercalados e (iv) das ressonâncias temáticas (conforme vimos na seção anterior).

\section{AS RELAÇÕES DIALÓGICAS NA MATERIALIDADE ENUNCIATIVA DOS SITES}

Bakhtin (2003[1979]) explica que todo enunciado é pleno de ressonâncias e ecos de outros enunciados. Os enunciados não são indiferentes uns com os outros, pois se conhecem e se atravessam mutuamente. Além disso, essas relações com os enunciados do outrem e, por conseguinte, com seus juízos de valor (quaisquer posições valorativas), determinam o todo do enunciado.

Bakhtin (2003[1979]) explica que as relações dialógicas, como já dito, são relações de sentido que se realizam nos enunciados. De acordo com o autor, dois enunciados, ao se confrontarem em um dado plano de sentido, em dada situação de interação, acabam sempre por estabelecer relações dialógicas, que, para o autor, são relações semânticoaxiológicas. Além disso, devemos entender que as relações dialógicas são, por natureza, extraverbais, contudo não podem, simultaneamente, serem separadas do discurso. 
Bakhtin (1998[1975]; 2003[1979]; 2008[1929]) nos lembra que as relações dialógicas são possíveis não apenas entre enunciados integrais, mas também (a) com qualquer parte significante do enunciado; (b) entre estilos de língua, dialetos sociais; e (c) com a enunciação como um todo, desde que essas partes sejam vistas como o todo do enunciado que representam. Bakhtin (2008[1929]) assim esclarece essa questão:

As relações dialógicas são possíveis não apenas entre enunciações integrais (relativamente), mas o enfoque dialógico é possível a qualquer parte significante do enunciado [...], se ouvimos nela a voz do outro. Por isso, as relações dialógicas podem penetrar no âmago do enunciado [...], por outro lado, as relações dialógicas são possíveis entre os estilos de linguagem [...]. Por último, as relações dialógicas são possíveis também com a própria enunciação como um todo [...]. (BAKHTIN, 2008[1929], p. 210-211).

Como já mencionado na seção anterior, observamos que, nos sites das SETURs, as relações dialógicas se materializam por meio: da reenunciação do discurso do outro, das relações entre esferas sociodiscursivas, da intercalação de gêneros e da ressonância entre horizontes temáticos.

(a) a reenunciação do discurso do outro: como explica Bakhtin (1998[1975], p. 86), "orientado para seu objeto, o discurso penetra neste meio dialogicamente perturbado e tenso de discursos de outrem, de julgamentos e de entonações. Ele se entrelaça com eles em interações complexas [...].” Nos sites das SETURs, podemos perceber como o enquadramento dialógico do discurso do outro projeta efeitos de credibilidade e convencimento, à medida que faz ascender discursos de avaliação, validação e reconhecimento político, público ou pessoal sobre as informações turísticas apresentadas. O discurso do outro, por assim dizer, legitima as informações apresentadas, criando graus de confiabilidade (GIDDENS, 1991[1990]) e validação. Como explica Bakhtin (1998[1975]):

A concepção do seu objeto, por parte do discurso, é um ato complexo: qualquer objeto "desacreditado" e "contestado" é aclarado por um lado e, por outro, é obscurecido pelas opiniões sociais multidiscursivas e pelo discurso de outrem dirigido a ele. É neste jogo complexo de claro-escuro que penetra o discurso, impregnando-se dele, limitando suas próprias facetas semânticas e estilísticas. (BAKHTIN, 1998[1975], p. 86, grifos do autor).A orientação dialógica é naturalmente um fenômeno próprio a todo o discurso. Trata-se da orientação natural de qualquer discurso vivo. Em todos os seus caminhos até o objeto, em todas as direções, o discurso se encontra com o discurso de outrem e não pode deixar de participar, com ele, de uma interação viva e tensa. [...] O discurso nasce no diálogo como sua réplica viva, forma-se na mútua-orientação dialógica do discurso de outrem no interior do objeto. A concepção que o discurso tem de seu objeto é dialógica. (BAKHTIN, 1998[1975], p. 88-89, grifos nossos). 
Para Bakhtin (2006[1929], p. 150), “o discurso citado é o discurso no discurso, a enunciação na enunciação, mas é, ao mesmo tempo, um discurso sobre o discurso, uma enunciação sobre a enunciação”. A partir desse panorama, podemos entender que o discurso do outro é uma das formas de dialogismo presente nos diversos usos da linguagem que fazemos nas diferentes interações sociais. Na retomada de posições, na recuperação de idéias ou pontos de vista ou na simples citação de discursos outros, estamos nos apropriando enunciativamente do discurso de outrem.

Além disso, compreender o funcionamento do discurso de outrem é entender o processo de reenunciação, isto é, a enunciação de discursos enunciados. Segundo Rodrigues (2001, p. 173), "o enquadramento do discurso do outro no enunciado cria a perspectiva, o fundo dialógico que é dado ao discurso introduzido". Dessa forma, podemos entender que o discurso de outrem enquadrado no discurso do autor submete-se a processos de reenunciação e revaloração, à medida que a situação de interação na qual o(s) discurso(s) se engendra(m) influencia diretamente nos sentidos dos discursos em diálogo/enquadramento. Em outras palavras, o discurso do outro enquadrado no discurso do autor é reenunciado e revalorado segundo o objeto e o projeto discursivos e os participantes dessa situação, sofrendo determinadas mudanças e transformações de significados. "A palavra alheia introduzida no contexto do discurso estabelece com o discurso que o enquadra não um contexto mecânico, mas uma amálgama química [...]” (BAKHTIN, 1998[1975], p. 141).

Para Bakhtin (1998[1975]), o contexto que absorve o discurso de outrem constrói um fundo dialógico cujas influências, transformações e revalorações podem ser extremamente marcantes. Nos sites das SETURs, o enquadramento do discurso do outro constrói diferentes efeitos de sentidos, isto é, projeções valorativos de autoridade e validação das informações.

Os efeitos de autoridade são construídos a partir da reenunciação do discurso do outro, apresentando uma determinada voz de credibilidade ou de legitimação das informações apresentadas. À medida que se introduzem vozes de autoridades, especialistas ou representantes de determinadas instituições ou a voz de sujeitos intimamente relacionados com os fatos reportados, a voz do outro funciona como um discurso de autoridade, isto é, legalizador. Por exemplo abaixo a reenunciação do discurso do outro com efeito de autoridade:

Publicada em: 29,08:2011
Jovens vislumbram Horizonte Profissional
O passeio é uma chance para que o jovem descubra novas
possibilidades profissionais com as quais nunca havia se
confrontado antes.

Leia mais
Publicada em: 29,08,2011

Profissionais de Ipojuca participam de workshop de capacitação

O evento já passou por Recife e Fernando de Noronha e é uma grande oportunidade para aprender como melhorar o serviço de hospedagem.

Leia mais

Exemplo 1. O enquadramento do discurso de outrem no site da SETURPE.

(b) relação entre esferas sociodiscursivas 


\section{INVESTIDOR}

Saiba como realizar investimentos turísticos na Bahia. Confira nossas áreas e oportunidades de investimentos, legislação e licenciamento ambiental.

\section{TRANSPARÊNCIA}

Relatórios da prestação de contas, dos recursos aplicados e o quadro das ações em curso.

\section{ZONAS TURÍSTICAS}

Conheça todas as 13 zonas turísticas da Bahia os destinos indutores e municípios âncora e seus respectivos links para o Portal Bahia.com.br.

Exemplo 2. A relação de discursos de esferas diferentes: esfera econômica, política e turística na página virtual da SETURBA.

Consoante à compreensão dos gêneros do discurso como enunciados que relativamente se estabilizam nas diversas situações sociais de interação, Bakhtin (2003[1979]) propõe as esferas sociais como princípio organizador dos gêneros, isto é, são concretizações dentre as diversas formas de comunicação social. As esferas tipificam as situações de interação, estabilizando os enunciados que nela circulam, originando gêneros do discurso particulares dessa esfera. Segundo Rodrigues (2001, p. 70), "cada esfera conhece e „aplica“ os seus próprios gêneros”. Compreende-se, dessa forma, que as características particulares da constituição e do funcionamento dos gêneros do discurso estão vinculadas às especificidades das esferas sociais nas quais estes funcionam, circulam e se organizam. Com isso, cada campo organiza suas formas típicas de comunicação social, à medida que,

As relações de produção e a estrutura sociopolítica que delas diretamente deriva determinam todos os contatos verbais possíveis entre indivíduos, todas as formas e os meios de comunicação verbal: no trabalho, na vida política, na criação ideológica. Por sua vez, das condições, formas e tipos da comunicação verbal derivam tanto as formas como os temas dos atos de fala. [...] Estas formas de interação verbal acham-se muito estreitamente vinculadas às condições de uma situação social dada e reagem de maneira muito sensível a todas as flutuações da atmosfera social. (BAKHTIN, 2006[1929], p. 43).

Como já analisado na seção anterior acerca das imagens em discurso que se entrecruzam na materialidade enunciativa das páginas virtuais das SETURs, observamos que esses discursos emergem de esferas sociais particulares que, por sua vez, se relacionam dialogicamente nesses sites. A esfera da política, da economia, do entretenimento, do ecossistema e da sustentabilidade parecem agir em confluência, relativamente estabilizando discursos que ora se confrontam, ora se distanciam (conforme vimos na seção 4). Cada esfera social, com sua função socioideológica particular e suas condições sociodiscursivas próprias, formula, na interação social, determinados gêneros, específicos a essa esfera. Dessa forma, entendemos que os 
gêneros correspondem a situações de interação verbal típicas (RODRIGUES, 2001), e apresentam na sua constituição, as finalidades e as condições sociodiscursivas da esfera na qual são produzidos e circulam. Veja, por exemplo, discursos de esferas da política, da economia, da cultura que se entrecruzam no site da SETUR de Alagoas abaixo:

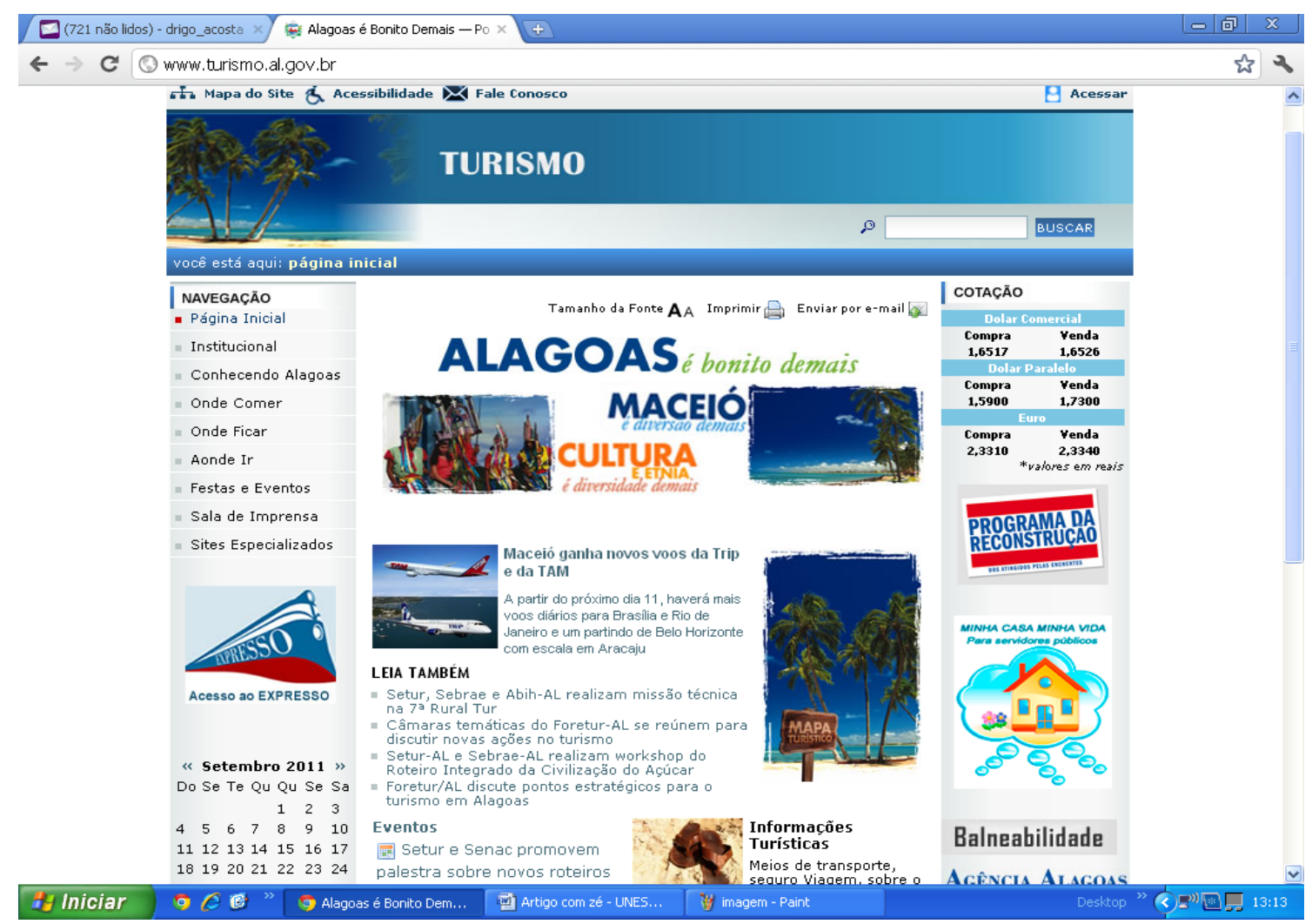

Exemplo 3. Esferas da política, da economia e da cultura que se entrecruzam no site da SETUR de AL.

(c) intercalação dialógica de gêneros do discurso outros: para Bakhtin (1998[1975], p. 74-75), os gêneros intercalados são unidades básicas de composição do discurso. “[...] ele[s] admite[m] uma variedade de vozes sociais e de diferentes ligações e correlações (sempre dialogizadas em maior ou menor grau). Bakhtin (1998[1975]) explica o papel dos gêneros intercalados à luz do gênero romance. Contudo, podemos relacionar seus esclarecimentos a discursos de outras esferas, como o discurso de nosso objeto de investigação. O autor assim esclarece:

Os gêneros [intercalados] conservam habitualmente a sua elasticidade estrutural, a sua autonomia e a sua originalidade linguística e estilística. [...] Cada um desses gêneros possui suas formas semânticoverbais para assimilar os diferentes aspectos da realidade. [...] Os gêneros intercalados podem ser diretamente intencionais ou totalmente objetais, ou seja, desprovidos inteiramente das intenções do autor. [...] enfim, os gêneros intercalados ou enquadrados são as formas fundamentais para introduzir e organizar o plurilinguismo no romance. (BAKHTIN, 1998[1975], p. 124-125). 


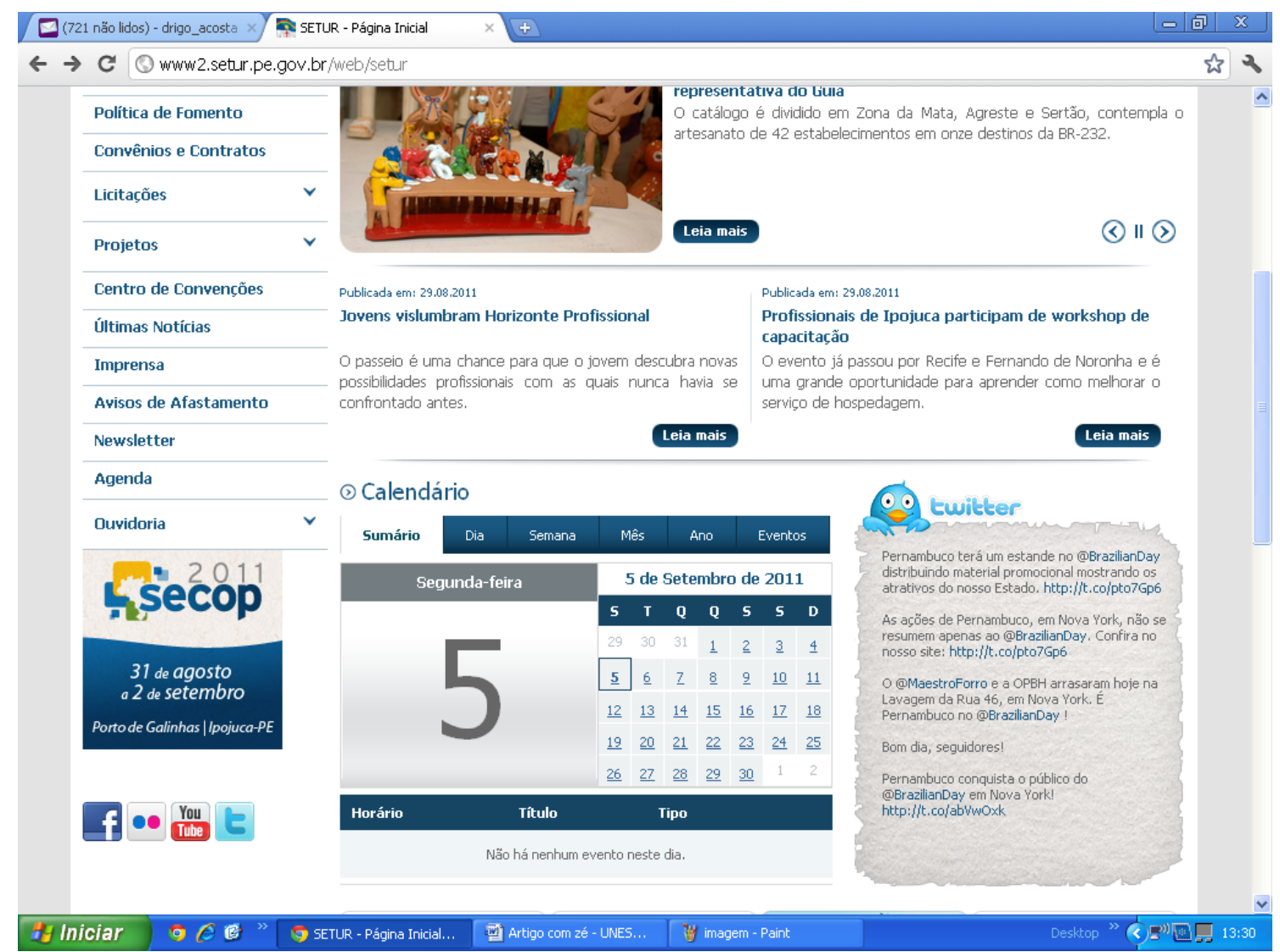

Exemplo 4. Os gêneros intercalados aos sites da SETURPE: fotografias, calendários, notícias, redes sociais, etc.

(d) ressonância temática: como já visto na seção anterior, nas páginas virtuais das SETURs, há um entrecruzamento dialógico de conteúdos semânticoobjetais que, por sua vez, funcionam como marcas validativas das informações. O que podemos entender, em relação às relações dialógicas, é que estas funcionam à luz de determinados sentidos: legitimidade, credibilidade, validade, segurança, avaliação positiva e valorização apresentam-se como os diversos sentidos ou "efeitos de sentido" que se projetam por meio das relações dialógicas entre discursos nos sites das SETURs.

Em síntese, por meio das análises, podemos compreender que,

Discurso é uma unidade de produção de sentido que é parte das práticas simbólicas de sujeitos concretos e articulada dialogicamente às suas condições de produção, bem como vinculada constitutivamente com outros discursos. Mobilizando as formas da língua e as formas típicas de enunciados em suas condições sóciohistóricas de produção, o discurso constitui seus sujeitos e inscreve em sua superfície sua própria existência e legitimidade social e histórica. (SOBRAL, 2009, p. 101).

Em outras palavras, a análise nos conduz a entender que, ao analisarmos o discurso, estamos, de fato, analisando um processo social de produção de sentidos que envolvem 
conjuntamente sujeitos, instituições, contextos e valores que, em confluência, trabalham na e para a construção de significados únicos, reiteráveis, concretos e historicamente situados.

\section{CONSIDERAÇÕES FINAIS}

De acordo com Bakhtin (1998[1975]),

[...] a língua não conserva mais formas e palavras neutras "que não pertencem a ninguém”; ela torna-se como que esparsa, penetrada de intenções, totalmente acentuada. Para a consciência que vive nela, a língua não é um sistema abstrato de formas normativas, porém uma opinião plurilíngüe concreta sobre o mundo. Todas as palavras evocam uma profissão, um gênero, uma tendência, um partido, uma obra determinada, uma pessoa definida, uma geração, uma idade, um dia, uma hora. Cada palavra evoca um contexto ou contextos, nos quais ela viveu sua vida socialmente tensa; todas as palavras e formas são povoadas de intenções.

[...] A linguagem não é um meio neutro que se torne fácil e livremente a propriedade intencional do falante, ela está povoada ou superpovoada de intenções de outrem. Dominá-la, submetê-la às próprias intenções e acentos é um processo difícil e complexo. (BAKHTIN, 1998[1975], p. 100, grifos do autor).

Como bem explica o autor, a linguagem, em todos seus campos de atuação, entra em confluência com outras linguagens, à medida que nunca se encontra neutra ou impessoal, mas sempre carrega de ecos e ressonâncias de linguagens outras. "A palavra da língua é uma palavra semi-alheia.” (BAKHTIN, 1998[1975], p. 100).

O discurso das páginas das SETURs investigadas constrói-se sob essa ótica: discursos que ora se interpelam, se confrontam, se distanciam, ora se confundem povoados de intenções. Seja à luz da criação intencional de "elos de confiança" entre o público e a instituição, seja sob o âmbito da procura de sentidos específicos de legitimidade, credibilidade, validade e segurança, o discurso das SETURs, em duas múltiplas dimensões estilístico-composicionais, está “sempre” à procura da adesão.

Vimos como as imagens em discurso, as relações dialógicas e a construção de confiabilidade institucional trabalham juntos para a construção de orientações semântico-axiológicas (valorativas) específicas: o convencimento de que as informações apresentadas em seus sites são confiáveis e verídicas. Confiar nos sites institucionais (sistemas abstratos, em termos giddensianos) parece ser um caminho "fiel" de acesso às informações. Como esclarece Bakhtin (1998[1975], p. 98), “[...] todas as linguagens [...] são pontos de vista específicos sobre o mundo, formas de sua interpretação verbal, perspectivas específicas objetais, semânticas e axiológicas.” 


\section{REFERÊNCIAS}

ACOSTA-PEREIRA, R. O gênero jornalístico notícia: dialogismo e valoração. Florianópolis, 2008. 229 p. Dissertação (Mestrado em Linguística) Centro de Comunicação e Expressão, Universidade Federal de Santa Catarina.

Cronotopos, esfera e autoria no gênero notícia impressa. Letra Magna,

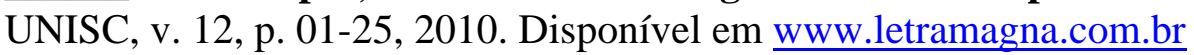

. O gênero jornalístico notícia impressa: dialogismo, avaliatividade e estilo.

Revista de Letras (PPGL/UFTPR), 2011a. (Prelo).

. A reenunciação e as relações dialógicas no gênero jornalístico notícia: visadas, projeções e discursividade. Revista Gatilho (PPGL/ UFJF. Online), 2011b. (Prelo).

BAKHTIN, M. M. Questões de Literatura e de Estética: Teoria do Romance. 4 ed. São Paulo: UNESP, 1998[1975].

. Estética da Criação Verbal. 4. ed. São Paulo: Martins Fontes, 2003[1979].

[VOLOSHINOV]. Marxismo e Filosofia da Linguagem: Problemas

fundamentais do método sociológico na ciência da linguagem. $12^{\circ}$ ed. São Paulo: Hucitec, 2006[1929].

. Problemas da Poética de Dostoiévski. Trad. Paulo Bezerra. 3. ed. Rio de Janeiro: Forense Universitária, 2008[1929].

GIDDENS, A. As conseqüências da modernidade. São Paulo: Editora da UNESP, 1991[1990].

A política da mudança climática. Rio de Janeiro: Zahar, 2010.

; BECK, U; LASH, S. Modernização reflexiva: política, tradição e estética na ordem social moderna. São Paulo: Editora da UNESP, 1994.

MACHADO, I. Gêneros discursivos. In: BETH, B. Bakhtin: conceitos-chave. São Paulo: Contexto, 2007.

RODRIGUES. R. H. A Constituição e Funcionamento do Gênero Jornalístico Artigo: Cronotopo e Dialogismo. Tese (Doutorado em Lingüística Aplicada e Estudos da Linguagem - LAEL - PUCSP). São Paulo: PUCSP, 2001.

.Os Gêneros do Discurso na Perspectiva Dialógica da Linguagem: A Abordagem de Bakhtin. In: MEURER, J. L; BONINI, A. \& MOTTA-ROTH, D. Gêneros: Teorias, Métodos e Debates. São Paulo: Parábola, 2005. p. 152-183. 
ROHLING DA SILVA, N. O Gênero Entrevista Pingue-Pongue: Reenunciação, Enquadramento e Valoração do Discurso do Outro. Dissertação de Mestrado. PGL. Universidade Federal de Santa Catarina, Florianópolis, 2008.

SOBRAL, A. Do dialogismo ao gênero: as bases do pensamento do Círculo de Bakhtin. Campinas/SP: mercado de Letras, 2009. 